\title{
HUBUNGAN KADAR HBA1C DENGAN RESIKO NEFROPATI DIABETIKUM PADA PASIEN DM TIPE 2 DI RSUD H. ABDUL MANAP KOTA JAMBI
}

\author{
Susan Tarawifa1, Samuel Batara Bonar1, Imanuel Sitepu2 \\ 1 Program Studi Kedokteran, Fakultas Kedokteran dan Ilmu Kesehatan Universitas \\ Jambi \\ 2 Bagian Patologi Klinik, RSUD H. Abdul Manap Kota jambi
}

\begin{abstract}
Rhinosinusitis as Complications in Patients with Poly Allergy Abstract : Correlation Of Hba1c And Nephropathy Diabetic Risk In $\mathbf{H}$. Abdul Manap Hospital, Jambi. Chronic hyperglycemia in diabetes is related with dysfunction or multiple organs failure such as the kidneys (diabetic nephropathy). Control of hyperglycemia in patients with type 2 diabetes is very important. HbA1c is an examination of glycemic status in patients with type 2 diabetes and microalbuminuria examination is useful for early monitoring of the risk of diabetic nephropathy. This study aims to find out the correlation between HbA1c levels and the risk of nephropathy diabetic nephropathy in type $2 \mathrm{DM}$ patients in $\mathrm{H}$. Abdul Manap Hospital, Jambi City. This study used an observational analytic method with a cross-sectional approach and consecutive sampling technique. From the results of 30 study subjects, it was found that patients aged $56-65$ years old were $66.7 \%$. Based on gender, $66.7 \%$ were women and $33.3 \%$ were men. The results of uncontrolled $\mathrm{HbA} 1 \mathrm{c}$ levels showed a $50 \%$ risk of diabetic nephropathy and $50 \%$ normal. The results of controlled HbA1c levels obtained $62.5 \%$ normal and $37.5 \%$ at risk of diabetic nephropathy. Statistic analysis showed that the $p$-value $=0.426$. in this study, there was no significant correlation between HbA1c levels and the risk of diabetic nephropathy in type 2 DM patients in $\mathrm{H}$. Abdul Manap Hospital, Jambi City
\end{abstract}

Keywords:, Diabetic Nephropathy, HbA1c, Mikroalbuminuria

\begin{abstract}
Abstrak : Hubungan Kadar Hba1c Dengan Resiko Nefropati Diabetikum Pada Pasien Dm Tipe 2 Di Rsud H. Abdul Manap Kota Jambi. Hiperglikemia kronis pada diabetes mellitus tipe 2 berhubungan dengan disfungsi atau kegagalan beberapa organ tubuh seperti ginjal (nefropati diabetikum). Pengendalian hiperglikemia pada penderita DM tipe 2 sangat penting dan tidak boleh diabaikan karena berhubungan dengan morbiditas dan mortalitas penderita DM tipe 2 tersebut. HbA1c merupakan salah satu pemeriksaan status glikemik pada penderita DM tipe 2 dan pemeriksaan mikroalbuminuria berguna untuk pemantauan dini resiko nefropati diabetikum. Penelitian ini bertujuan untuk mengetahui hubungan kadar HbA1c dengan Resiko Nefropati Diabetikum pada pasien DM tipe 2 di RSUD H. Abdul Manap Kota Jambi. Penelitian ini menggunakan metode analitik cross-sectional dengan menggunakan teknik consecutive sampling sesuai dengan kriteria inklusi. Analisis data dilakukan univariat dan bivariate menggunakan uji Chi-Square. Dari hasil 30 subjek penelitian, didapatkan pasien dengan usia $56-65$ sebesar 66 , jenis kelamin perempuan sebesar $66,7 \%$ perempuan. Hasil kadar HbA1c tidak terkontrol didapatkan hasil $50 \%$ beresiko nefropati diabetikum dan 50\% normal. Hasil kadar HbA1c yang terkontrol didapatkan hasil $62,5 \%$ normal dan $37,5 \%$ beresiko nefropati diabetikum Hasil uji statistik menunjukkan bahwa nilai $\mathrm{p}$-value $=0,42$ yang berarti tidak adanya hubungan yang bermakna antara kadar HbA1c dengan resiko nefropati diabetikum pada pasien DM tipe 2 di RSUD H. Abdul Manap Kota Jambi
\end{abstract}

Kata Kunci: Nefropati Diabetikum, HbA1c, Mikroalbuminuria 


\section{PENDAHULUAN}

Diabetes Melitus (DM) merupakan penyakit kronis yang terjadi akibat ketidakmampuan pankreas untuk menghasilkan insulin atau ketika tubuh tidak dapat menggunakan insulin yang dihasilkan secara efektif. (WHO 2017) Diabetes yang umum terjadi adalah DM tipe 1 dan DM tipe 2. Berdasarkan hasil Riset Kesehatan Dasar (RISKESDAS), terdapat eningkatan prevalensi DM di Indonesia berdasarkan diagnosis dokter pada penduduk umur $\geq 15$ tahun dari $1,5 \%$ pada tahun 2013 menjadi 2,0\% pada tahun 2018. Di provinsi Jambi prevalensi DM pada umur $\geq 15$ tahun adalah sebesar $1,5 \%$ (RISKESDAS, 2018).

Diabetes melitus tipe 2 merupakan tipe diabetes yang paling banyak ditemukan dengan proporsi $90 \%$ dari seluruh kasus DM di seluruh dunia. Dengan besarnya proporsi tersebut, kelompok ini berisiko paling tinggi terhadap sejumlah komplikasi DM (PERKENI, 2011). Komplikasi DM dapat digolongkan menjadi komplikasi akut dan komplikasi kronik. Beberapa contoh dari komplikasi akut adalah ketoasidosis diabetikum diabetikum (KAD), koma hiperosmolar non ketotik, hipoglikemia. Sedangkan komplikasi kronik dari DM dibagi menjadi 2: komplikasi mikrovaskuler dan makrovaskuler. Komplikasi tersebut terjadi karena tidak terkendalinya kadar glukosa darah. Komplikasi makrovaskuler sering terjadi pada penderita DM adalah penyakit jantung koroner (PJK), gagal jantung kongestif dan stroke, sedangkan komplikasi mikrovaskuler adalah nefropati diabetikum, retinopati (kebutaan) dan neuropati yang terjadi akibat adanya hiperglikemia persisten dan pembentukan protein terglikasi yang menyebabkan dinding pembuluh darah semakin lemah dan terjadinya penyumbatan pada pembuluh darah kecil (Hendromartono, 2014).

Salah satu komplikasi mikrovaskuler yang sering terjadi adalah Nefropati diabetikum dengan prevalensi sebanyak $20-40 \%$ pasien DM tipe 2 mengalami progresivitas menjadi nefropati. Nefropati diabetikum adalah suatu gejala klinis yang ditandai dengan adanya albuminuria menetap yaitu 30-300 $\mathrm{mg} / 24 \mathrm{jam}$ atau $>200 \mu \mathrm{g} /$ menit dalam minimal dua kali pemeriksaan pada kurun waktu 3 sampai 6 bulan dan merupakan penyebab utama End Stage Renal Disease (ESRD) pada pasien diabetes melitus khususnya pasien DM tipe 2 (PERKENI, 2011).

Progresifitas pasien DM tipe 2 menjadi nefropati diabetikum disebabkan oleh beberapa hal, salah satunya akibat kontrol glikemik yang buruk. Kontrol glikemik merupakan keterkendalian kadar gula darah pasien diabetes melitus yang dapat dibedakan menjadi kontrol glikemik jangka panjang dan kontrol glikemik sesaat. (Nelms et al, 2011) Pengukuran kontrol glikemik jangka panjang adalah dengan melihat kadar Glycated Haemoglobin (HbA1c). HbA1c merupakan marker yang rutin digunakan untuk kontrol glikemik jangka panjang dan dapat digunakan sebagai indikator terjadinya komplikasi pada pasien DM. HbA1c menggambarkan kadar gula darah selama 120 hari terakhir. Sedangkan kontrol glikemik sesaat dapat diukur dengan melihat kadar gula darah puasa dan kadar gula darah 2 jam postprandial (Ketema, 2015).

Kenaikan persentase kadar HbA1c menunjukkan peningkatan kadar glukosa yang berada dalam darah yang digambarkan sebagai kondisi hiperglikemia. Keadaan hiperglikemia ini mempengaruhi kadar glukosa yang masuk ke glomerulus ginjal. Keadaan inilah yang akan menyebabkan keadaan arteriosklerosis hyalin, peningkatan tekanan dalam glomerulus, peningkatan dari laju filtrasi glomerulus (hiperfiltrasi) yang merupakan tahapan pertama dalam nefropati diabetikum, sel mesangial membentuk matriks struktural yang meningkatkan ukuran glomerulus, meningkatkan permeabilitas sehingga protein seperti albumin yang seharusnya tidak dapat masuk ke glomerulus menjadi lolos filtrasi (Ketema, 2015, Nelms et al, 2011). 


\section{METODE}

Penelitian ini $\begin{gathered}\text { merupakan } \\ \text { penelitian analitik observasional } \\ \text { dengan pendekatan cross-sectional }\end{gathered}$
denan dengan menggunakan data primer berupa hasil pemeriksaan laboratorium kadar HbA1c dan mikroalbuminaria serta data sekunder yang diambil dari rekam medik pasien DM di Rumah Sakit Umum Daerah H. Abdul Manap Kota Jambi pada bulan Mei-September 2019. Sampel penelitian sebanyak 30 sampel dengan teknik pengumpulan sampel menggunakan cara consecutive sampling. Analisis data dilakukan dua tahap yaitu analisis univariat dan bivariate menggunakan uji chi-squre dengan tingkat signifikan $p=0,05 \%$ dan tingkat kepercayaan sebesar $95 \%$.

\section{HASIL}

Penelitian ini dilakukan untuk mengetahui apakah ada hubungan antara kadar $\mathrm{HbA1C}$ dengan resiko nefropati diabetikum pada pasien DM tipe 2. Penelitian dilaksanakan di poli penyakit dalam RSUD H. Abdul Manap Kota Jambi. Sampel yang diperoleh dari penelitian ini, didapatkan hasil sebagai berikut :

Tabel 1. Distribusi Responden berdasarkan karakteristik sampel

\begin{tabular}{lcc}
\hline Variabel & Jumlah (n) & Persentase (\%) \\
\hline Jenis kelamin & & \\
Laki-laki & 10 & 33,3 \\
perempuan & 20 & 66,7 \\
\hline Usia & 3 & 10 \\
$36-45$ & 7 & 23,3 \\
$46-55$ & 20 & 66,7 \\
$56-65$ &
\end{tabular}

Tabel 2. Hasil Pemeriksaan Laboratorium

\begin{tabular}{lcc}
\hline Variabel & Jumlah $(\mathrm{n})$ & Persentase $(\%)$ \\
\hline Kadar HbA1c & & \\
Tidak Terkontrol $(>6,5 \%)$ & 22 & 73,3 \\
Terkontrol (<6,5\%) & 8 & 23,7 \\
\hline Resiko Nefropati Diabetikum & & \\
mikroalbuminuria & 14 & 46,7 \\
normal & 16 & 53,3 \\
\hline
\end{tabular}

Berdasarkan hasil penelitian terhadap 30 orang sampel, didapatkan karakteristik mayoritas berjenis kelamin perempuan 20 orang $(66,7 \%)$ dan berusia diantara 56-66 tahun sebanyak 20 orang $(66,7 \%)$. (tabel 1$)$. Hasil pemeriksaan laboratorium terhadap 30 orang tersebut didapatkan hasil berupa kadar HbA1c yang tidak terkontrol pada 22 orang $(73,3 \%)$ dan terkontrol sebanyak 8 orang $(23,7 \%)$. (tabel 2). Pada pemeriksaan mikroalbuminaria, didapatkan hasil normal atau disebut dengan tidak beresiko sebanyak 16 orang $(53,3 \%)$ dan beresiko nefropati diabetikum (mikroalbuminaria) sebanyak 14 orang
$(46,7 \%)$. Pada hasil analisis bivariate, didapatkan hasil pada tabel 3 di bawah.

Berdasarkan tabel 3 didapatkan hasil yaitu dari total $100 \%$ sampel kadar HbA1c tidak terkontrol didapatkan hasil $50 \%$ beresiko nefropati diabetikum dan $50 \%$ normal. Sedangkan dari total $100 \%$ sampel dengan kadar HbA1c yang terkontrol didapatkan hasil $62,5 \%$ normal dan $37,5 \%$ beresiko nefropati diabetikum Berdasarkan hasil uji analisis bivariat dengan menggunakan uji Chi-square didapatkan hasil $\mathrm{p}$-value = $0,426(p>0,05)$ 
Tabel 3. Hubungan HbA1c dengan Resiko nefropati Diabetikum

\begin{tabular}{lcccc}
\hline \multirow{3}{*}{ Kadar HbA1c } & \multicolumn{2}{c}{$\begin{array}{c}\text { Resiko Nefropati } \\
\text { Diabetikum }\end{array}$} & $\begin{array}{c}\text { Total } \\
\text { n (\%) }\end{array}$ & P-value \\
\cline { 2 - 3 } & $\begin{array}{c}\text { Beresiko } \\
\mathbf{n}(\%)\end{array}$ & $\begin{array}{c}\text { Normal } \\
\mathbf{n}(\%)\end{array}$ & & \\
\cline { 2 - 3 } Tidak terkontrol & $11(50)$ & $11(50)$ & $22(100)$ & \\
terkontrol & $3(37,5)$ & $5(62,5)$ & $8(100)$ & 0,426 \\
total & $14(46,7)$ & $16(53,3)$ & $30(100)$ & \\
\hline
\end{tabular}

\section{PEMBAHASAN}

Pada penelitian ini didapatkan hasil bahwa responden berjenis kelamin perempuan sebanyak 20 orang $(66,7 \%)$ dan laki-laki sebanyak 10 orang $(33,3 \%)$. Jenis kelamin berpengaruh terhadap patogenesis suatu penyakit, misalnya pada DM tipe II. Budiyanto (2015), menyatakan bahwa kecenderungan DM pada perempuan lebih tinggi daripada lakilaki, hal ini dapat berhubungan dengan lebih tingginya kejadian obesitas pada perempuan (Rondonuwu, 2016).

Penelitian ini sesuai dengan teori yang menyatakan kejadian DM lebih banyak terjadi pada perempuan karena penurunan hormon estrogen terutama saat masa menopause. Estrogen dan progesteron mampu meningkatkan respons insulin dalam mengontrol kadar glukosa sehingga pada saat masa menopause respon insulin menurun akibat rendahnya kadar estrogen dan progesteron. Faktor-faktor lain yang berpengaruh adalah indeks masa tubuh perempuan yang sering tidak ideal sehingga hal ini dapat menurunkan sensitivitas respons insulin (Aaberg, 2013).

Karakteristik berdasarkan usia didapatkan hasil bahwa usia responden terbanyak berada di rentang usia 5665 tahun yaitu sebanyak 20 orang $(66,7 \%)$. Hasil penelitian ini sesuai dengan Pangemanan (2014), seseorang dengan usia diatas 55 tahun lebih beresiko terjadi DM dan intoleransi glukosa karena adanya penurunan fungsi tubuh misalnya penurunan kemampuan sel $\beta$ pankreas memproduksi insulin untuk metabolisme glukosa ataupun sel tubuh yang resisten terhadap insulin (Pangemanan, 2014).

Nefropati Diabetik

(ND)

merupakan kelainan degeneratif vaskuler ginjal dan merupakan komplikasi yang sering terjadi pada penderita DM (Ketema, 2015). Nefropati diabetik ditandai dengan adanya mikroalbuminuria (30$300 \mathrm{mg} / 24 \mathrm{jam}$, atau $20 \mu \mathrm{g} / \mathrm{menit}$ ) tanpa adanya gangguan ginjal, disertai dengan peningkatan tekanan darah sehingga mengakibatkan menurunnya filtrasi glomerulus dan akhirnya menyebabkan gagal ginjal tahap akhir. Hasil pemeriksaan mikroalbuminuria pada penelitian didapatkan sebanyak 14 orang $(46,7 \%)$ beresiko menderita nefropati diabetikum. Progresifitas pasien DM tipe 2 menjadi nefropati diabetikum disebabkan oleh beberapa hal, salah satunya akibat kontrol glikemik yang buruk. (Ketema,2015) Kontrol glikemik jangka panjang dapat diukur dengan pemeriksaan HbA1c, dimana pada penelitian ini didapatkan sebanyak 22 orang $(67,7 \%)$ memiliki kadar HbA1c tidak terkontrol.

Hasil analisis bivariate, didapatkan sampel yang berisiko nefropati diabetikum ada sebanyak 14 orang dimana 11 orang $(78,6 \%)$ diantaranya memiliki kadar HbA1c yang tidak terkontrol sedangkan sampel yang normal (tidak beresiko nefropati diabetikum) berjumlah 16 orang dan 5 orang $(31,3 \%)$ diantaranya memiliki kadar HbA1c yang terkontrol. Uji statistik pada penelitian ini menunjukkan tidak adanya hubungan yang bermakna antara kadar $\mathrm{HbA1C}$ dengan resiko nefropati diabetikum pada 
pasien DM Tipe 2 di RSUD H. Abdul Manap Kota Jambi (p-value >0,05). Hasil penelitian ini sejalan dengan penelitian yang dilakukan oleh Ayu Lirani (2016) yang menunjukkan bahwa tidak terdapat hubungan yang signifikan antara kadar $\mathrm{HbA1c}$ dengan kejadian nefropati diabetikum (Ayu, 2016). Hasil yang berbeda ditunjukkan oleh penelitian yang dilakukan oleh Wahyuni dkk yang mendapatkan hasil bahwa terdapat hubungan positif kuat antara $\mathrm{HbA} 1 \mathrm{c}$ dengan mikroalbuminaria (Wahyuni, 2016). Perbedaan ini dapat disebabkan oleh keterbatasan rentang waktu penggambaran kadar glukosa dalam darah yaitu 3 bulan mengikuti masa hidup sel darah terhadap hasil mikroalbuminuria sebagai penanda kerusakan ginjal yang bersifat irreversible.

Dalam pengendalian hiperglikemia dibutuhkan pengaturan gaya hidup dan terapi farmakologi sebagai tatalaksana yang penting bagi penderita DM tipe 2. Hiperglikemia persisten menyebabkan komplikasi mikrovaskular seperti nefropati diabetikum yang merupakan penyebab utama gagal ginjal pada DM tipe 2 (Sacks, 2011). Pemantauan komplikasi ginjal bisa dilakukan dengan pemeriksaan proteinuria, yaitu melalui pemeriksaan urinalisis rutin atau penurunan klirens kreatinin namun akan menjadi terlambat karena hasilnya hanya didapatkan apabila sudah terjadi kerusakan ginjal yang luas. Oleh karena itu pemeriksaan mikroalbuminuria menjadi pemeriksaan yang diperlukan dalam pemantauan dini resiko nefropati diabetikum (Sacks, 2011).

Perbedaan hasil penelitian ini dengan penelitian lainnya yang mendapatkan hubungan yang bermakna bisa disebabkan beberapa faktor seperti rerata umur subjek penelitian dan jenis kelamin subjek penelitian. Diagnosis DM tipe 2 yang sering terlambat juga bisa menjadi faktor yang menyebabkan adanya perbedaan dari hasil penelitian lainnya. Tidak adanya data lamanya subjek penelitian menderita DM tipe 2 dan kurangnya data proteinuria pada pemilihan subjek penelitian menjadi kelemahan dari penelitian ini.

\section{KESIMPULAN}

Berdasarkan hasil penelitian dan analisis data yang telah dilakukan pada pasien DM tipe 2 di Poli Penyakit Dalam RSUD $H$. Abdul Manap didapatkan kesimpulan bahwa sebagian besar responden berjenis kelamin perempuan yaitu sebanyak 22 orang $(66,7 \%)$ dan berusia di antara 56-65 tahun sebanyak 20 orang $(66,7 \%)$. Hasil pemeriksaan kadar $\mathrm{HbA} 1 \mathrm{c}$, persentase yang tidak terkontrol sebesar 73,3\% sedangkan persentase yang terkontrol sebesar $26,7 \%$ dan memiliki nilai kadar $\mathrm{HbA} 1 \mathrm{c}$ rerata $8,82 \%$ (tidak terkontrol). Pemeriksaan mikroalbuminaria dilakukan untuk menilai risiko nefropati diabetikum dan didapatkan persentase yang normal sebesar $53,3 \%$ dan persentase yang mikroalbuminuria sebesar $46,7 \%$ dan memiliki nilai rerata $81.83 \mathrm{mg} / \mathrm{L}$ (mikroalbuminuria). Hasil uji uji statistik menunjukkan pvalue : 0,426 $(>0,05)$ yang berarti tidak adanya hubungan yang signifikan antara variabel kadar HbA1c dengan variabel resiko nefropati diabetikum.

\section{DAFTAR PUSTAKA}

Aaberg, M. L., Burch, D. M., Hud, Z. R., \& Zacharias, M. P. 2013. Gender differences in the onset of diabetic neuropathy. Journal of Diabetes and Its Complications.

Ayu Lirani, Emma 2016. Hubungan Kontrol Glikemik (HbA1c) dengan Kejadian Nefropati Diabetik Pasien Diabetes Melitus Tipe 2 di RSUD Dr. Moewardi Surakarta. 2016. (Diakses 1 oktober 2019 dari:

https://eprints.uns.ac.id/25031/)

Hendromartono. 2014. Nefropati Diabetik. dalam Sudoyo AW, Setiyohadi B, Alwi I, Simadibrata M, Setiati S. Buku Ajar IImu Penyakit Dalam Jilid II edisi VI. Jakarta: Interna Publishing

Kementerian Kesehatan RI. 2018. Riset Kesehatan Dasar (Diakses 4 April 
2019

dari

http://www.depkes.go.id/)

Ketema, E.B. dan Kibret, K.T., 2015. Correlation of fasting and postprandial plasma glucose with HbA1c in assessing glycemic control; systematic review and meta-analysis. Archives of Public Health

Nelms M, et al. 2011. Nutrition Therapy and Pathophysiology 2nd International Edition. Stamford: Cengage Learning.

Pangemanan D, Mayulu N. 2014. Analisis Faktor Resiko Penyebab Terjadinya Diabetes Melitus Tipe 2 Pada Wanita Usia Produktif Dipuskesmas Wawonasa

PB PERKENI. 2011. Konsensus Pencegahan dan Pengendalian Diabetes Melitus Tipe 2 di Indonesia. (Diakses 4 april 2019 dari:

http:www.academa.edu/4053797 /revisifinal_Konsesus_DM_Tipe_2 _Indonesia_2011)

Rondonuwu, R. G, Rompas, S \& Bataha, Y. 2016. Hubungan Antara Perilaku Olahraga Dengan Kadar Gula Darah Penderita Diabetes Mellitus Di Wilayah Kerja Puskesmas Wolaang Kecamatan Langowan Timur

Sacks, D.B, et al., 2011. Guidelines and Recommendations for Laboratory Analysis in the Diagnosis and Management of Diabetis Mellitus, Diabetes Care, Volume 34. (Diakses 4 April 2019 dari http://care.diabetesjournals.org/c ontent/34/6/ e61.full.pdf+html)

Wahyuni, Fitri. 2016. Korelasi Kadar Hemoglobin Terglikasi dengan Urinary Albumin Creatinine Ratio pada Diabetes Melitus Tipe 2. (Diakses secara online 1 oktober 2019 dari: http://scholar.unand.ac.id/4399/ 5/Tesis)

World Health Organization. 2017. Global Report on Diabetes. (Diakses 2 April 2019) dari http://www.who.int/mediacentre/ factsheets/f s312/en/) 